\section{Pharmacokinetics of sufentanil in the elderly surgical patient}

The effect of age on the distribution and elimination of sufentanil was studied in seven elderly ( $77 \pm 5 y r$, mean $\pm S D)$ and seven younger ( $4 \mathrm{I} \pm 15 \mathrm{yr}$ ) neurosurgical patients. Following a single $I V$ bolus of sufentanil $2 \mu \mathrm{g} \cdot \mathrm{kg}^{-1}$ multiple arterial samples were obtained at timed intervals and plasma concentrations of sufentanil were measured by radioimmunoassay. Pharmacokinetic variables were calculated from the derived compartmental models. The initial volume of distribution was significamly smaller in the elderly patients $\left(310 \pm 109 \mathrm{ml} \cdot \mathrm{kg}^{-1} \mathrm{vs} 491 \pm 112\right.$ $\mathrm{ml} \cdot \mathrm{kg}^{-1}$ mean $\pm S D$ ). Elimination half-lives, plasma clearances, and total volumes of distribution were similar for elderly and younger subjects. Six of seven elderly patients required administration of naloxone at the termination of surgery 10 achieve an alequate rate of ventilation (> eight breaths $\cdot \mathrm{min}^{-1}$ ) while only one younger patient required antagonism of ventilatory depression. The authors believe that age-related differences in the action of sufentanil cannot be accounted for by the observed differences in the initial volume of distribution. It is concluded that alterations in pharmacodyamics appear to be of greater importance in the prolonged opioid effect seen in the elderly.

L'effet de l'âge sur la distribution et l'élimination du sufentanil a été étudié chez sept patients âgés ( $77 \pm 5$ ans, moyenne $\pm S D$ ) et sept patients moins âgés $(4 I \pm 15$ ans) devant subir des

\section{Key words}

ANAESTHESIA: geriatric;

ANAESTHETICS, INTRAVENOUS: sufentanil; PHARMACOKINETICS; sufentanil.

From the Department of Anesthesiology, College of Physicians and Surgeons, Columbia University, and the Anesthesiology Service, Presbyterian Hospital, New York, NY 10032

U.S.A.

*Present address: Department of Anesthesiology, Brigham and Women's Hospital, Boston, MA, U.S.A.

This study was supported in part by a grant from Janssen Pharmaceutica Inc.

Address correspondence to: Dr. R. S. Matteo, Dept. of Anesthesiology, College of Physicians and Surgeons, Columbia University, 622 West 168th Street, New York, NY 10032 U.S.A. procédures neuro-chirurgicales. Après un bolus intraveineux unique de sufentanil de $2 \mu \mathrm{g} \cdot \mathrm{kg}^{-1}$, des échamillons artériels multiples on été obtenus à des intervalles réguliers et des concentrations plasmatiques de sufentanil ont été mesurées par radio-immuno-essai. Les variables pharmacocinétiques ont été calculées. Le volume initial de distribution était significativement plus petit chez les patients plus âgés $1310 \pm 109 \mathrm{ml} \cdot \mathrm{kg}^{-1}$ moyerne $\pm S D$ ). Les demi-vies d'élimination, les clairances plasmatiques, les volumes totaur de distribution éraient similaires pour les patients âgés et les sujets plus jetunes. Six des sept patients âgés ont requis l' administration de naloxone à la fin de la chirurgie afin d'acquérir une fréquence de ventilation adéquale ( $>8$ respirations $\cdot$ min $^{-1}$ ) alors qu' un seul patien plus jeune a requis un antagonisme de sa dépression respiratoire. Les auteurs croient que les différences reliées à l'age dans l' effer du sufentanil ne peuvent être altribuées aux différences du volume de distribution initial. On conclut que les altérations de la pharmacodynamique apparaissent plus importante dans la prolongation des effets des opiacés observés chez les gens âgés.

It is well established that physiological changes accompanying advanced age can alter drug distribution and elimination (pharmacokinetics). Changes which may affect drug distribution in the elderly, especially in the case of opioids, are a decrease in total body water, ${ }^{1,2}$ decreased total cell mass, ${ }^{3}$ a relative decrease in lean body mass, ${ }^{3,4}$ increased body fat, ${ }^{3,4}$ and decreased serum albumin $^{5}$ with decreased protein binding of drugs. In addition, drug elimination in the elderly may be altered by decreased cardiac output, ${ }^{6}$ reduced hepatic blood flow with a slowed delivery of drug to the liver, ${ }^{7,8}$ and a possible decrease in active metabolism of drugs in the liver. ${ }^{9}$ Furthermore, studies have clearly demonstrated that the elderly are more sensitive to the analgesic and respiratory depressant effects of opioids than younger patients. ${ }^{10-12}$

With this background in mind, this study was designed to determine the pharmacokinetics of sufentanil in elderly surgical patients.

\section{Methods}

Following Institutional Review Board approval, informed consent was obtained from all patients. Seven elderly (age 
over $70 \mathrm{yr}$ ) and seven younger (less than $60 \mathrm{yr}$ ) patients undergoing elective neurosurgery were studied. In the elderly group, the operations included three carotid endarterectomies, three lumbar laminectomies and one cervical laminectomy. In the younger group, there were five lumbar laminectomies, one cervical laminectomy and one transphenoidal adenomectomy. All patients had normal liver function and no evidence of cardiac failure. Premedication in most cases consisted of intramuscular secobarbital $(50-120 \mathrm{mg})$ and atropine $(0.3-0.5 \mathrm{mg})$, though three of the elderly received atropine alone. Anaesthesia was induced with thiopentone $3-6 \mathrm{mg} \cdot \mathrm{kg}^{-1}$ IV and tracheal intubation was facilitated with succinylcholine (1.0-1.5 mg $\mathrm{kg}^{-1}$ IV) following precurarization with vecuronium $1 \mathrm{mg}$ IV. Anaesthesia was maintained with $\mathrm{N}_{2} \mathrm{O}, \mathrm{O}_{2}(60,40$ per cent $)$, isoflurane $0.25-0.5$ per cent (inspired concentration) and a continuous infusion of vecuronium to obtain muscle relaxation. Body temperature was continuously monitored via an oesophageal probe and varied no more than $1^{\circ} \mathrm{C}$ throughout the entire procedure. A steady state end-tidal carbon dioxide tension $\left(\mathrm{ETCO}_{2}\right)$ was established in each patient which ranged between 31-37 mmHg, after which an arterial blood sample was obtained to determine arterial carbon dioxide tension $\left(\mathrm{PCO}_{2}\right)$. The steady state $\mathrm{ETCO}_{2}$ was maintained throughout the procedure. At this time, sufentanil (2 $\mu \mathrm{g} \cdot \mathrm{kg}^{-1}$ ) was injected intravenously as a bolus. Heparinized arterial blood samples were obtained at 1, 3, 5, 10, $15,20,30,45,60 \mathrm{~min}$ and at half-hour intervals thereafter to four hr. Plasma was separated and frozen until assayed by radioimmunoassay (sensitivity $0.1 \mathrm{ng} \cdot \mathrm{ml}^{-1}$; coefficient of variation 8.5 per cent). ${ }^{13}$ At least $30 \mathrm{~min}$ before the termination of surgery, isoflurane was discontinued and anaesthesia then maintained with $\mathrm{N}_{2} \mathrm{O}$ and vecuronium. At the end of anaesthesia, following reversal of the muscle relaxant, it was determined if the patient's respiration was so depressed as to require a narcotic antagonist. The criterion for respiratory depression was eight breaths $\cdot \mathrm{min}^{-1}$ or less. If required, naloxone in 50 $\mu \mathrm{g}$ increments was given intravenously. The time from injection of sufentanil until extubation of each patient was noted.

Both bi- and tri-exponential equations were fitted to the plasma concentration-time curves from each patient, using weighted, nonlinear least squares regression analysis (BMDP). ${ }^{14} \mathrm{~A}$ weighting function of $\left(\frac{1}{X_{i}^{2}}\right)$ was used. The best fit for the data was then determined by the method of Boxenbaum. ${ }^{15}$ Pharmacokinetic variables were calculated by using a standard method for bolus IV injection of a drug. ${ }^{16}$ Total volume of distribution was determined by the area method. Comparisons of the pharmacokinetic variables between elderly and young patients were made

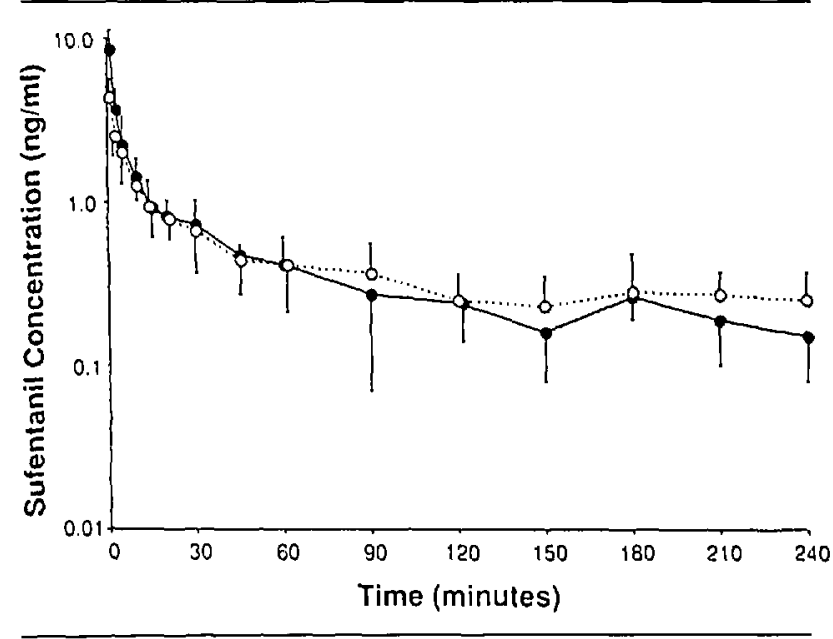

FIGURE Plasma concentration-time course curves for elderly (O--O) and younger controls $\left(\mathrm{O}_{-}-\mathrm{O}\right)$ after a single intravenous dose $\left(2 \mu \mathrm{g} \cdot \mathrm{kg}^{-1}\right)$ of sufentanil. The concentration data are presented on a logarithmic scale. Values are means \pm SD.

by applying Student's t test for unpaired data (twotailed). The groups' characteristics and intraoperative conditions were similarly compared. The male:female ratio was compared using chi-square. The threshold for statistical significance was $P<0.05$.

\section{Results}

The demographic characteristics of the groups, intaoperative conditions and selected laboratory data are presented in Table I. When the two study groups were compared with regard to age, weight, sex, duration of anaesthesia, arterial $\mathrm{CO}_{2}$ tension, body temperature, total protein and serum albumin, only in age were the groups significantly different. No patient in either group required a blood transfusion. The plasma concentration-time course curves for each group are displayed in the Figure.

Plasma decrement curves for all patients were best

TABLE I Demographic, intraoperative conditions and laboratory data $($ mean $\pm \mathrm{SD})$

\begin{tabular}{|c|c|c|c|}
\hline & $\begin{array}{l}\text { Elderly } \\
(n=7)\end{array}$ & $\begin{array}{l}\text { Younger } \\
\text { controls } \\
(n=7)\end{array}$ & $P$ \\
\hline Age $(y r)$ & $77 \pm 5$ & $41 \pm 15$ & $<0.001$ \\
\hline Weight (kg) & $58 \pm 12$ & $67 \pm 12$ & NS \\
\hline $\operatorname{Sex}(F: M)$ & $4: 3$ & $4: 3$ & NS \\
\hline Duration anaesthesia $(\min )^{*}$ & $214 \pm 54$ & $245 \pm 55$ & NS \\
\hline Arterial $\mathrm{CO}_{2}$ tension $(\mathrm{mmHg})$ & $38 \pm 3$ & $40 \pm 3$ & NS \\
\hline Temperature $\left({ }^{\circ} \mathrm{C}\right)$ & $35.5 \pm 0.4$ & $35.8 \pm 0.6$ & NS \\
\hline Total protein $\left(g \cdot d^{-l}\right)$ & $6.0 \pm 0.8$ & $6.3 \pm 0.7$ & NS \\
\hline Albumin $\left(g \cdot \mathrm{dl}^{-1}\right)$ & $3.8 \pm 0.6$ & $4.1 \pm 0.6$ & NS \\
\hline
\end{tabular}

*Duration anaesthesia $=$ time from administration of sufentanil until extubation. 
TABLE II Pharmacokinetic variables (mean \pm SD)

\begin{tabular}{lccc}
\hline & Young, $n=7$ & Elderly, $n=7$ & $P$ \\
\hline $\begin{array}{l}\text { Elimination half-life (min) } \\
\text { Plasma clearance } \\
\left(\mathrm{ml} \cdot \mathrm{kg}^{-1} \cdot \mathrm{min}^{-1}\right)\end{array}$ & $137 \pm 68$ & $113 \pm 89$ & $\mathrm{NS}$ \\
$\begin{array}{l}\text { Initial volume of distribution } \\
\left(\mathrm{ml} \cdot \mathrm{kg}^{-1}\right)\end{array}$ & $18.3 \pm 7$ & $19.4 \pm 9$ & $\mathrm{NS}$ \\
$\begin{array}{l}\text { Total volume of distribution } \\
\left(\mathrm{ml} \cdot \mathrm{kg}^{-1}\right)\end{array}$ & $491 \pm 112$ & $310 \pm 109$ & $<0.02$ \\
\hline
\end{tabular}

described by two-compartment models. The pharmacokinetic variables are presented in Tables II and III. The initial volume of distribution was significantly smaller in the elderly than the younger patients. This reflects an initially higher plasma concentration of sufentanil in the elderly patients studied. There were no significant differences in any of the other pharmacokinetic variables when the elderly were compared with the younger controls. At the termination of surgery six of seven elderly patients and one of seven younger patients required administration of naloxone to achieve a rate of ventilation greater than eight breaths per minute.

\section{Discussion}

Clinical studies have clearly established that the elderly are more sensitive to the analgesic and respiratory depressant effects of narcotics than younger patients. ${ }^{10-12}$ Are these observations in the elderly related to the changes in the distribution and elimination (pharmacokinetics) of narcotics or changes in their action within the central nervous system?

Fentanyl and its analogues, sufentanil and alfentanil, exhibit many characteristics that could be influenced by the physiological changes that accompany the aging process. These drugs exhibit a high clearance with a high hepatic extraction ratio and are thus sensitive to changes in splanchnic blood flow. Sufentanil, alfentanil and fentanyl depend almost exclusively on phase 1 drug metabolism (N-demethylation, hydroxylation) in the liver. This process decreases with increasing age. ${ }^{9}$ Plasma protein binding is 92 per cent with sufentanil and alfentanil and slightly lower with fentanyl ( 84 per cent bound). Thus a decrease in serum albumin would make more free drug available for binding on the opiate receptors. These narcotics are lipophylic drugs with sufentanil having the greatest lipid solubility (octanol number, 1754). The elderly with increased total body fat might sequester more narcotic in their fatty tissues. All of these factors suggest that the pharmacokinetics of these narcotics would be markedly altered in the elderly.

The pharmacokinetics of fentanyl were first studied in elderly patients by Bentley et al. ${ }^{17}$ They reported that elderly patients (over age $60 \mathrm{yr}$ ), when compared with younger patients, had a reduced plasma clearance $(4.0 \pm$ 0.6 vs $\left.15.4 \pm 1.6 \mathrm{ml} \cdot \mathrm{min}^{-1} \mathrm{~kg}^{-1}\right)$ and a prolonged $\mathrm{t} \frac{1}{2} \beta$ (945 \pm 64 vs $265 \pm 22 \mathrm{~min}$ ). There was no significant age-related difference in volumes of distribution. In contrast, Scott and Stanski could not demonstrate any significant pharmacokinetic changes between the elderly and younger patients given fentanyl. ${ }^{18}$ Most recently, Singleton et al..$^{19}$ found the clearance of fentanyl to be similar in elderly and younger patients, while the steadystate volume of distribution was significantly smaller in the elderly. The concentration of fentanyl was greater in the elderly at one and four minutes after injection, but was not significantly different during the remainder of the study. These authors felt that any age-related differences in response to fentanyl were most likely related to a higher initial fentanyl concentration in the elderly.

Conflicting pharmacokinetic data have also been reported for alfentanil. Helmers et al. ${ }^{20}$ reported that when elderly patients (over age 65 years) were compared with younger controls the elderly exhibited decreased plasma clearance $\left(4.37 \pm 2.6 \mathrm{vs} 6.47 \pm 2.1 \mathrm{ml} \cdot \mathrm{min}^{-1} \mathrm{~kg}^{-1}\right)$ and a prolonged $t \frac{1}{2} \beta(137 \pm 33$ vs $83 \pm 23 \mathrm{~min})$. They found no difference in the volumes of distribution between the two groups. Again, Scolt and Stanski could find no age-related pharmacokinetic changes for alfentanil. ${ }^{18}$

Our pharmacokinetic data are similar to those previously reported for sufentanil in anaesthetized patients. Bovill et al. administered sufentanil $5 \mu \mathrm{g} \cdot \mathrm{kg}^{-1}$ to ten surgical patients and derived an elimination half-life of $167 \mathrm{~min}$, total volume of distribution of $2860 \mathrm{ml} \cdot \mathrm{kg}^{-1}$ and plasma clearance of $12.66 \mathrm{ml} \cdot \mathrm{kg}^{-1} \cdot \mathrm{min}^{-1} .{ }^{21}$ The control group of Sear et al., after receiving $2.5 \mu \mathrm{g} \cdot \mathrm{kg}^{-1}$ of sufentanil, had an elimination half-life of $185 \mathrm{~min}$, volume of distribution of about $2966 \mathrm{ml} \cdot \mathrm{kg}^{-1}$ and clearance of about $18.1 \mathrm{ml} \cdot \mathrm{kg}^{-1} \cdot \mathrm{min}^{-1} .^{22}$ These values are all in close agreement with control values previously reported by our group (elimination half-life $143 \mathrm{~min}$, volume of distribution $3518 \mathrm{ml} \cdot \mathrm{kg}^{-1}$, clearance $\left.17.3 \mathrm{ml} \cdot \mathrm{kg}^{-1} \cdot \mathrm{min}^{-1}\right)$ for neurosurgical patients receiving $4 \mu \mathrm{g} \cdot \mathrm{kg}^{-1}$ of sufentanil. ${ }^{23}$ The control values for kinetic variables in the present study fall well within the range established by previous investigators. This lends validity to the pharmacokinetic values we report in our elderly group. In addition, in this study there is no significant difference in serum albumin between the two groups. Thus, protein binding is not a factor in this study.

The age-related differences in the action of sufentanil reported in this study do not appear to be related to any difference in the major pharmacokinetic variables (i.e., plasma clearance, total volume of distribution, elimination half-life). The initial volume of distribution of sufentanil in the elderly, however, is significantly de- 
TABLE III Coefficients and exponents of fitted curves

\begin{tabular}{lllll}
\hline Patient & $A\left(n g \cdot l^{-1}\right)$ & $\alpha\left(\mathrm{min}^{-1}\right)$ & $B\left(n g \cdot l^{-1}\right)$ & $\beta\left(\mathrm{min}^{-1}\right)$ \\
\hline Elderly & & & & \\
1 & 8.70 & 0.163 & 0.626 & 0.0049 \\
2 & 4.90 & 0.146 & 0.411 & 0.0023 \\
3 & 3.44 & 0.243 & 1.114 & 0.0113 \\
4 & 7.25 & 0.173 & 0.642 & 0.0055 \\
5 & 12.35 & 0.392 & 0.589 & 0.0012 \\
6 & 5.48 & 0.442 & 1.040 & 0.0222 \\
7 & 4.12 & 0.195 & 0.519 & 0.0090 \\
Mean (SD) & $6.61 \pm 3$ & $0.25 \pm 0.12$ & $0.706 \pm 0.27$ & $0.009 \pm 0.007$ \\
\hline Younger controls & & & & \\
1 & 5.11 & 0.344 & 0.279 & 0.0030 \\
2 & 3.36 & 0.190 & 0.471 & 0.0042 \\
3 & 4.19 & 0.113 & 0.760 & 0.0090 \\
4 & 5.95 & 0.132 & 0.408 & 0.0042 \\
5 & 2.69 & 0.163 & 0.686 & 0.0041 \\
6 & 4.17 & 0.184 & 0.837 & 0.0053 \\
7 & 1.62 & 0.215 & 1.340 & 0.0254 \\
Mean (SD) & $3.88 \pm 1.5$ & $0.192 \pm 0.076$ & $0.683 \pm 0.35$ & $0.008 \pm 0.008$ \\
\hline
\end{tabular}

creased when compared with the younger controls. The decrease in the initial volume of distribution reflects a higher initial plasma concentration of the drug. It is attractive to postulate that this initial increase in sufentanil concentration may be responsible for age-related responses to the narcotic. In fact, Singleton ${ }^{19}$ has advanced this concept for fentanyl. The work of Scott and Stanski, ${ }^{18}$ however, appears to refute this concept. In a combined pharmacokinetic and pharmacodynamic study, Scott and Stanski infused either fentanyl or alfentanil in elderly and young. The electroencephalogram (EEG) was employed to measure narcotic action while blood samples were analyzed for each narcotic to quantitate drug distribution and elimination. In examining their data, it appears that the peak electroencephalographic response either coincides with or closely follows the peak serum narcotic concentrations. Further, once the narcotic infusions were stopped, serum concentrations of the drugs declined and concurrently the EEG's reverted towards the pre-narcotic control values. Since the action of the narcotics appears to follow serum concentration closely it does not appear that a brief initial increase in serum narcotic concentration would in and of itself account for the prolonged action of a narcotic.

The weight of most recent evidence now suggests that any prolongation of action of sufentanil and its analogues in elderly patients is unlikely to be related to changes in the classical pharmacokinetic variables of these drugs. Alteration in pharmacodynamic behavior appears to be of greater importance in the prolonged opioid effect seen in the elderly.

\section{References}

I Edelman IS, Leibman J. Anatomy of body water and electrolytes. Am J Med 1959; 27: 256-77.

2 Shock NW, Watkin DM, Yiengst BS et al. Age differences in water content of body as related to basal oxygen consumption in males. J Gerontol 1963; 18: 1-8.

3 Novak $L P$. Aging, total body potassium, fat-free mass and cell mass in males and females between ages 18-85 years. J Gerontol 1972; 27: 438-43.

4 Forbes $G B$, Reina JC. Adult lean body mass declines with age: some longitudinal observations. Metabolism 1970; 19: 653-63.

5 Woodford-Williams $E$, Alvarez AS, Webster D, Landless $D$, Dixon $M P$. Serum protein patterns in normal and pathological ageing. Gerontologia 1964; 10: 86-99.

6 Brandfonbrener $M$, Landowne $M$, Sick $N W$. Changes in cardiac output with age. Circulation 1955; 12: 551-66.

7 Bender $A D$. The effect of increasing age on the distribution of peripheral blood flow in man. J Am Geriar Soc $1965 ; 13: 192-8$.

8 Leithe ME, Hermiller JB, Magorien RD, Unverferth DV, Reier $C$. Effect of age on central and regional hemodynamics. Gerontology 1984; 30: 240-6.

9 Greenblatt DJ, Sellers EM, Shader RI. Drug disposition in old age. N Engl J Med 1982; 306: 1081-8.

10 Bellville JW, Forrest W Jr, Miller E, Brown BW Jr. Influence of age on pain relief from analgesics. JAMA 1971; 217: 1835-41.

11 Kaiko $R F$. Age and morphine analgesia in cancer patients with postoperative pain. Clin Pharmacol Ther 1980; 28: 823-6. 
12 Arunasalam K, Davenporl HT, Painter S, Jones JG. Ventilatory response to morphine in young and old subjects. Anaesthesia 1983; 38: 529-33.

13 Michiels $M$. Hendriks $R$, Heykants J. Radioimmunoassay of the new opiate analgesics alfentanil and sufentanil. Preliminary pharmacokinetic profile in man. J Pharm Pharmacol 1983; 35: 86-93.

14 Dixon W, Brown M, Engelman L et al. BMDP Statistical Software. Berkley: University of California Press, 1983.

15 Boxenbaum HG, Riegelman S. Elashoff RM. Statistical estimation in pharmacokinetics. J Pharmacokinet Biopharm 1974; 2: 123-48.

16 Wagner JG. Linear pharmacokinetic equations allowing direct calculation of many needed pharmacokinetic parameters from the coefficients and exponents of polyexponential equations which have been fitted to the data. J Pharmacokinet Biopharm 1976; 4: 443-67.

17 Bentley JB, Borel JD, Nenad RE Jr, Gillespie TJ. Age and fentanyl pharmacokinetics. Anesth Analg 1982; 61: 968-71.

18 Scott JC, Stanski DR. Decreased fentanyl and alfentanil dose requirements with age: a simultaneous pharmacokinetic and pharmacodynamic evaluation. J Pharmacol Exp Ther 1987; 240: 159-66.

19 Singleton MA, Rosen JI, Fisher DM. Pharmacokinetics of fentanyl in the elderly. Br J Anaesth 1988; 60: 619-22.

20 Helmers $H$, Van Peer A, Woestenborghs $R$, Noorduin $H$, Heykants $J$. Alfentanil kinetics in the elderly. Clin Pharmacol Ther 1984; 36: 239-43.

21 Bovill JG, Sebel PS, Blackbush CL, Oei-Lim V. Heykants $J$. The pharmacokinetics of sufentanil in surgical patients. Anesthesiology 1984; 61: 502-6.

22 Seer $J W$. Sufentanil disposition in patients undergoing renal transplantation: influence of choice of kinetic model. Br J Anaesth 1989; 63: 60-7.

23 Schwartz AE, Matteo RS, Ornstein E, Young WL, Thornhill $M$. Pharmacokinetics of sufentanil in neurosurgical patients undergoing hyperventilation. Br J Anaesth 1989; 63: 385-8. 